[24] Item post dicte missam contra mortalitem ponitur Evangelium sic incipiens Apprehendit pilatus Jesum put owte the Rubrice that is before the said gospell ${ }^{8}$

[25] Item in the generall sentence put owte all soche woordes as may seme to sounde any thing to the glorye of the Busshopp of Rome or derogacyon of the kinges gracys prerogatyve. ${ }^{29}$

28 This rubric precedes the Gospel of the Missa contra mortalitatem : 'Istud Evangelium compositum fuit per Johannem Papam xxii apud Avinionem tertio die ante decessum suum; pro quo concessit omnibus illud dicentibus vel audientibus, vere confessis et contritis, trecentos dies indulgentie: : ibid. $890^{*}$.

29 The general sentence is usually printed or written in English at the end of the Manual: Manuale secundum usum insignis Sarum, C. Endouiensis: Antwerp 1523 (STC 1645), fo. cxix ${ }^{\mathrm{v}}$. It is also found in Mirk's Festiall and the relevant section is edited in Letters of Thomas Cranmer, 281-2.

Jnl of Ecclesiastical History, Vol. 64, No. I, January 2013. C Cambridge University Press 2013 doi:10.1017/So022046912002667

\title{
The Eusebius Essay Prize
}

The Eusebius Essay Prize, of $£_{5}$ oo, is offered annually for the best essay submitted on a subject connected with any aspect of early Christian history, broadly understood as including the first seven centuries $\mathrm{AD} / \mathrm{CE}$. Scholars in any relevant discipline (theology, classics, late antique studies, Middle Eastern Studies etc.), whether established in their field or graduate students, are encouraged to enter the competition. Submissions from younger scholars are particularly welcomed. The essay should not exceed 8,ooo words, including footnotes, and for this year should be submitted by $3^{\circ}$ September. A judgement will be made at the end of November (the editors reserve the right not to award the prize if no essay of significant quality is submitted). The essay of the successful candidate will be published in the Journal, probably in the number appearing in July 2014. Other submissions entered into the competition may also be recommended for publication. All essays should be sent as two hard copies, prepared to journal style, to Mrs Anne Waites, Journal of Ecclesiastical History, Robinson College, Cambridge $\mathrm{CB}_{3}$ 9AN. 